\title{
The Effect Of Innovation Product, Service Quality To Customer Satisfaction And Customer Loyalty Of Banco Nacional De Comercio Timor-Leste/BNCTL Dili
}

\author{
Sanzinha dos Santos Branca ${ }^{1}$ Luh Komang Chandra Dewi ${ }^{2}$ Augusto da Conceição Soares ${ }^{3}$ \\ Master's Program, Institute of Business (IOB), Timor-Leste ${ }^{1}$ \\ Faculty of Economic and Business. UNTRIM, Bali, Indonesia ${ }^{2}$ \\ Master'sProgram, Institute of Business (IOB), Timor-Leste ${ }^{3}$
}

\begin{abstract}
The objective of this thesis is to analyze and explain: 1) The effect of product innovation to customers' satisfaction, 2) The effect of services quality to customers' satisfaction, 3) The effect of products' innovation to customers' loyalty. 4) The effect of services quality to customers' Loyalty. And 5) The Effect of customers' satisfaction to customers' loyalty. The data collection in this research through distribution of questioner to customers of BNCTL Bank in Dili. The sampling technique used is non-probability sampling with purposive sampling technique, total of 80 respondents were chosen. The data is analyzed by using descriptive statistic and inferential in path analysis With SMARTPLS. The result of the research shows that innovation product and service quality have positive and significant influence to customer satisfaction and customer's loyalty of Bank BCNTL in Dili. In addition, customer satisfaction have positive and significant influences to customer's loyalty. Therefore, the more BNCTL banks sold their innovating products according to the needs and desires of customers by paying attention to the three indicators, the customer satisfaction and loyalty will also increase. In addition, the better quality of service received by the customer, it will further increase the satisfaction and loyalty of customers of the BNCTL bank in Dili. Therefore, it is hoped that the bank will always pay attention to product innovations that are in accordance with the needs and desires of customers So that satisfaction and loyalty are also increases.
\end{abstract}

Keywords: Product Innovation, Service of quality, Satisfaction and Customer Loyalty.

\section{INTRODUCTION}

In line with the stability of economic, social and political development in the country of Timor-Leste, it is of great interest to business people to do business or invest in various fields, one of which is in the banking industry. Globalization encourages competition in the highly 
competitive banking industry, this is determined by anticipation and creativity for any changes in customer needs and behavior. Thus, every bank is required to be more creative and innovative in serving customers by offering products and services by providing quality services and better facilities. The intense competition in the business world presents various ways to meet customer satisfaction, namely by applying creativity and innovation to the products and services offered and paying attention to the quality of services available. (Buchari 2007).

In order to gain market share in a situation of tight banking business competition, each bank is required to implement a customer-oriented marketing strategy, the main factors being concerned are customer satisfaction and loyalty. Move and Minor (2000) explain that loyalty is a condition in which customers have a positive attitude towards product brands that are always innovated according to customer needs and desires so that customers have a commitment to the product and intend to always make repeated purchases over a long period of time. Customer loyalty will be high if a product is considered capable of providing the highest satisfaction so that customers do not think about switching to another bank product brand. Lovelock and Wirtz (2011).

Table 1.1. Product data for the BNCTL bank and the Mandiri bank in Dili.

\begin{tabular}{|c|l|l|l|}
\hline No & Name of bank & \multicolumn{1}{|c|}{ Adress } & \multicolumn{1}{|c|}{ King of products } \\
\hline 1 & BNCTL Bank & $\begin{array}{l}\text { Floor 2 Timor } \\
\text { Plaza CB2, } \\
\text { Obrigado } \\
\text { Baracks, DIT } \\
\text { Aimutin. }\end{array}$ & $\begin{array}{l}\text { Daily savings with regular } \\
\text { ATMs, Hau nia future / } \\
\text { HNF savings time } \\
\text { deposits, loans / credits } \\
12 \% \text { pa. }\end{array}$ \\
\hline 2 & Mandiri Bank & $\begin{array}{l}\text { Colmera, floor 2 } \\
\text { Timor Plaza. }\end{array}$ & $\begin{array}{l}\text { Daily savings with ATM } \\
\text { P24, Future saving (HNF), } \\
\text { time deposits, loans / } \\
\text { credit 11\%pa and SDB } \\
\text { (safe deposit box) }\end{array}$ \\
\hline
\end{tabular}

Source: https://www.bnctl.tl_\&_https://mandaridili.tl

Based on table 1.1 product innovations at the BNCTL bank, Dili in 2018 which are compared to Bank Mandiri Dili Timor-Leste. Bank Mandiri has another product innovation in 2018, namely offering loans with loan interest of only $11 \%$ pa, no need for a loan witness, fast credit disbursement process, daily savings with ATMP24 and having SDB (safe deposit box) 
products. So independent customers always feel happy and satisfied with the good service of Bank Mandiri. (Mandiri ,Dili, 2019)

Meanwhile, the bank BNCTL Dili has not made any product innovation on credit products, namely the old and complicated credit process, the loan interest rate is $12 \%$ pa. Daily savings with regular ATMs do not use ATM machines from other banks, there is no SDB (safe deposit box). Thus BNCTL bank customers always complain that BNCTL bank services are not good. (Interviews and direct observation by the author) in the field, customers complain about the phenomena described above, that is the phenomenon of product innovation at the BNCTL Dili bank. Based on surveys (interviews) in the field, there were several BNCTL bank customers who had saved for a very long time, namely 5 years and above and had / used more than one product, namely daily saving, future savings and loan funds. The above phenomenon is a positive gap about customer loyalty.

With these gaps and phenomena that have been described, it can be supported by previous research conducted by Antanegoro (2017), which suggests that product innovation and service quality have a positive and significant effect on customer loyalty. And satisfaction has an effect on customer loyalty and is supported by research from Sinurat et al (2017), which shows that innovation has a positive effect on customer loyalty and service quality has an effect on customer loyalty. So this research will be studied about the topic. "The influence of product innovation, service quality on customer satisfaction and customer loyalty at Banco Nasional de Comercio de Timor-Leste (BNCTL) Dili."

\section{Formulation of the problem}

In the background description, the problem formulation:

1. How is the influence of product innovation on customer satisfaction at the BNCTL Dili bank?

2. How is the effect of service quality on customer satisfaction at the BNCTL Dili bank?

3. How is the effect of product innovation on customer loyalty at the BNCTL Dili bank?

4. How is the effect of service quality on customer loyalty at the BNCTL Dili bank?

5. How is the effect of satisfaction on customer loyalty at the BNCTL Dili bank?

\section{Research purposes}

1. To analyze and explain the effect of product innovation on customer satisfaction at the BNCTL Dili bank. 
2. To analyze and explain the effect of service quality on customer satisfaction at the BNCTL Dili bank.

3. To analyze and explain the effect of product innovation on customer loyalty at the BNCTL Dili bank.

4. To analyze and explain the effect of service quality on customer loyalty at the BNCTL Dili bank.

5. To analyze and explain the effect of satisfaction on customer loyalty at the BNCTL Dili bank.

\section{Theoretical and practical benefits}

Provide information and thoughts about the effect of product innovation, service quality, and customer satisfaction on customer loyalty. As a reference for future studies. As well as a reference for BNCTL bank decision making in marketing strategies

\section{LITERATURE REVIEW}

\section{Definition of Product Innovation.}

According to Martensen and Dahlgaard, (1999). Product innovation is innovation that is used in all potential company operations to create people's minds and imaginations that ultimately create customers.

\section{Product Innovation indicators}

According to Hubeis 2012, there are several indicators that can be used to measure product innovation among others: (1). Design changes. (2). Technical innovation, (3). New product development.

\section{Definition of Service Quality (SERQUAL)}

Parasumaran et al (2003) state that service quality is the level of excellence expected for a customer assessment of the service received to fulfill his wishes as a customer.

\section{Service Quality Dimensions}

Dimensions (SERVQUAL) according to Parasuraman quoted by Tjiptono (2011) there are 5 (five) dimensions are:

1). Tangibles 2). Reliability 3). Responsiveness, 4. Assurance, 5. Empathy

\section{Definition of Customer Satisfaction}

According to Tjiptono (2012) and Lupioyadi (2008). Customer satisfaction is the level of a person's feelings for a product and service after being used and comparing the performance or 
results he perceives compared to his expectations, if the results are felt in accordance with expectations, the customer will feel satisfaction with these results. Satisfaction is the result of a customer's perception or customer impression of the service, price, complete and as expected, so the customer will feel satisfied with these products or services.

\section{Indicators of Customer Satisfaction}

Nauman and Giel (Sulistyo, 1998), there are 4 indicators of customer satisfaction, namely: 1) Service. 2) Price. 3) Complete. 4) As expected.

\section{Definition of Customer Loyalty}

According to Kotler and Keller (2013), Customer Loyalty is a deeply held commitment to buy or re-support a preferred product or service in the future even though the influence of the situation and marketing efforts has the potential to cause customers to switch to other company's products and services.

\section{Indicators of Customer Loyalty}

Indicators of loyalty from Kotler and Keller (2012) and Tjiptono (2007) that can be used to measure customer loyalty are:

1) Brand, 2) Repeat purchase, 3) Retention, 4) Referrals).

\section{Framework}

This framework illustrates that product innovation affects customer satisfaction, service quality affects customer satisfaction, product innovation affects customer loyalty, service quality affects customer loyalty and customer satisfaction affects customer loyalty. Supported by Research Antanegoro et al (2017), that product innovation has a positive effect on customer satisfaction and loyalty

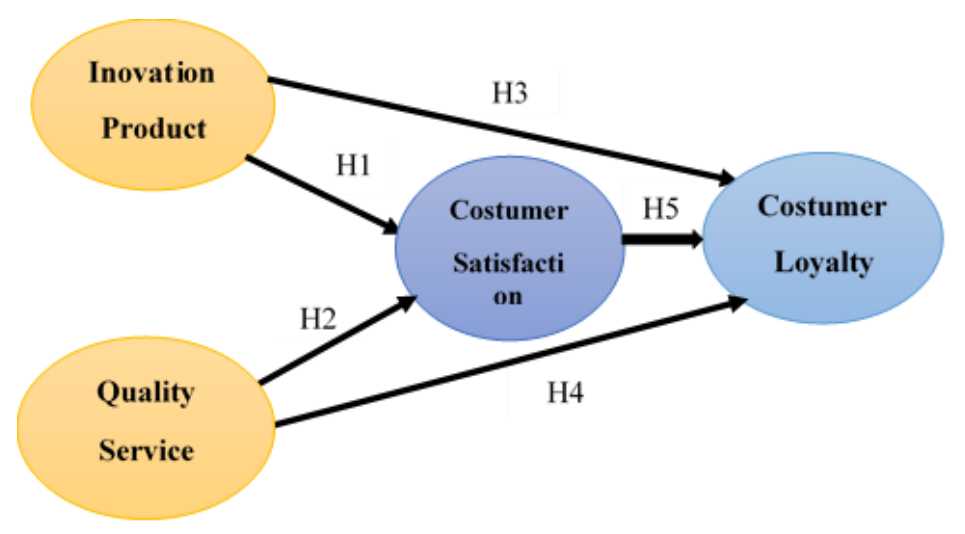

Figure 3.1 Conceptual Framework 


\section{Research Hypothesis}

H1: Product innovation has a positive and significant effect on customer satisfaction.

H2: Service quality has a positive and significant effect on customer satisfaction.

H3: Product innovation has a positive and significant effect on customer loyalty.

H4: Service quality has a positive and significant effect on customer loyalty.

H5: Customer satisfaction has a positive and significant effect on customer loyalty.

\section{RESEARCH METHOD}

\section{The scope of research}

Research (explanatory research), which explains the relationship between variables through hypothesis testing (Ghozali, 2005). The aim is to find out and explain the relationship of a cause and effect between innovation and service quality variables which are exogenous variables with endogenous variables, namely satisfaction and customer loyalty.

\section{Research sites}

The location of this research is Banco Nacional de comercio de Timor-Leste (BNCTL) Dili, while the research subjects are the customers of BNCTL Dili.

\section{Research Population}

The population in this study were customers of BNCTL banks, in the city of Dili, namely, the general public, civil servants, small and medium enterprises (UKM), who were a sample of at least 1 year and were BNCTL customers until 2019, who were the respondents in this study.

\section{Sample}

The sampling technique used is non-probability sampling with purposive sampling technique (Sugiyono, 2011). Because in this study have criteria to be a sample or respondent. Hair at al (1998) in Sugiyono (2009) suggests that the sample size is at least 5 to 10 for each estimated parameter so that in this study the researchers used 16 parameters so that $5 \times \mathrm{n}=5 \times 16=80$. From the results of the calculation of the formula, the number of samples used in this study as many as 80 respondents.

\section{Types and Sources of Data}


Quantitative data comes from respondents' responses to product innovation, service quality, customer satisfaction and customer loyalty to bank products provided by the BNCTL Dili bank, which are then elaborated and explained in numerical form.

Qualitative data, the data that is described in the form of numbers, based on the characteristics of the respondents. Included in qualitative data that can be converted into quantitative data.

Data source:

Primary data: obtained through questionnaires, namely the results of respondents from BNCTL Dili bank customers, who meet the criteria for being respondents (Supramono and Oktavian, 2005.

\section{Secondary Data.}

From the source website of the BNCTL bank, the internet, and literature, which is contained in the journal, in the form of a literature review containing endogenous and exogenous variables.

\section{Data collection technique}

Data collection techniques through 3 ways namely interviews, questionnaires, documentation 
Table 4.1. Construct Classification

\begin{tabular}{|c|c|c|c|}
\hline No & Variable & Dimensions & Indicator \\
\hline 1 & $\begin{array}{lr}\text { Innovation } & \text { Product } \\
\left(\mathbf{X}_{1}\right) & \\
\text { Hubeis } \quad(2012), \\
\text { Martensen and } \\
\text { Dahgaard (1999) }\end{array}$ & $\begin{array}{l}\text { a. Design Change (X1.1) } \\
\text { b. technical Innovation } \\
(\mathrm{X} 1.2) \\
\text { c. New product } \\
\text { development }\left(\mathrm{X}_{1.3}\right)\end{array}$ & $\begin{array}{l}\text { 1. Creating new products according to market needs } \\
\text { (X1.1.1) } \\
\text { 2. Serving Professionally (X1.2.1) } \\
\text { 3. Facilitate the process of using products and services } \\
\text { (X1.3.1) }\end{array}$ \\
\hline 2 & $\begin{array}{l}\text { service quality }\left(\mathbf{X}_{2}\right) \\
\text { Parasuraman quoted } \\
\text { (Tjiptono 2011) }\end{array}$ & $\begin{array}{ll}\text { a. } & \text { Tangible } \mathrm{X}_{2.1} \\
\text { b. } & \text { Reliability } \mathrm{X}_{2.2} \\
\text { c. } & \text { Responsiveness } \mathrm{X}_{2.3} \\
\text { d. } & \text { Assurance } \mathrm{X}_{2.4} \\
\text { e. } & \text { Empathy } \mathrm{X}_{2 .}\end{array}$ & $\begin{array}{l}\text { 1. Company employees with good performance (X2.1.1) } \\
\text { 2. The company provides correct information (X2.2.1) } \\
\text { 3. The ability of company employees to serve quickly } \\
\text { (X2..3.1) } \\
\text { 4. The company has a polite attitude towards customers } \\
\text { (X2.4.1) } \\
\text { 5. The company pays genuine attention (X2.5.1) }\end{array}$ \\
\hline 3 & $\begin{array}{l}\text { Costumer } \\
\text { Satisfaction }\left(\mathbf{Y}_{1}\right) \\
\text { Lupioyadi } \\
(2008) \text { and Tjiptono } \\
(2012), \\
\text { Naumann and Giel } \\
\text { (Sulistyo, 1998) }\end{array}$ & $\begin{array}{ll}\text { a. } & \text { Service }\left(\mathrm{Y}_{1.1}\right) \\
\text { b. } & \text { Price }\left(\mathrm{Y}_{1.2}\right) \\
\text { c. } & \text { Complete }(\mathrm{Y} 1.3) \\
\text { d. } & \text { according to } \\
& \text { expectations } \\
& \left(\mathrm{Y}_{1.4}\right)\end{array}$ & $\begin{array}{l}\text { 1. Customers are satisfied with the quality of service } \\
\text { provided (Y1.1.1) } \\
\text { 2. Companies offer prices for products and services } \\
\text { according to their quality (Y1.2.1) } \\
\text { 3. Companies offering products and services always } \\
\text { vary (Y1.3.2) } \\
\text { 4. The company innovates products according to } \\
\text { customer wishes (Y1.4.1 }\end{array}$ \\
\hline 4 & $\begin{array}{l}\text { Customer } \text { Loyalty } \\
\left(\mathbf{Y}_{2}\right) \\
\text { Kotler \& kaller } \\
(2012), \text { Tjiptono } \\
(2007), \quad \text { Huriyati } \\
(2010) .\end{array}$ & $\begin{array}{ll}\text { a. } & \text { Brand }\left(\mathrm{Y}_{1.1}\right) \\
\text { b. } & \text { Repeat Purchase } \\
& \left(\mathrm{Y}_{2.2)}\right. \\
\text { c. } & \text { Retention }\left(\mathrm{Y}_{2.3}\right) \\
\text { d. } & \text { Referrals }\left(\mathrm{Y}_{2.4}\right)\end{array}$ & $\begin{array}{l}\text { 1. Consumers continue to use the product consistently } \\
\text { (Y2.1.1) } \\
\text { 2. Customers remain customers and do not switch } \\
\text { (Y2.2.1) } \\
\text { 3. Customers keep recommending because complaints } \\
\text { are quickly handled. (Y2.3.1) } \\
\text { 4. Customers feel the company's products and services } \\
\text { are the best (Y2.4.1) }\end{array}$ \\
\hline
\end{tabular}

\section{Measurement Scale}

In the study using the Likert scale adopted by Sugiono (2011), namely: a score of 5 for respondents 'answers strongly agree (SS), score 4 for respondents' answers agree (S), score 3 for respondents 'answers disagree (TS), Score 2 for respondents' answers Neutral (N) and a score of 1 for respondents' answers strongly disagree (STS).

\section{Validity and Reliability Test}

The measurement is declared valid if the KMO (Kaiser meyer olkin) has a patience greater than 0.70 . The validity of the indicators can also be traced by looking at the correlation image values. The Cronbach Alpha coefficient (a) ranges from 0 to 1. In general, internal consistency is considered to occur when the $\alpha$ value is greater than or equal to 0.7 . Then $\alpha$ values ranging from 0.6 to 0.7 can be used (Hair et al., 2010) 
The meter is said to be reliable if it is said to be consistent if several measurements of the same subject are not different. The variable is declared reliable if the Cronbach Alpha coefficient is> 0.6. The formula for Alpha Cronbach is (Petter, 2007)

\section{Data analysis technique}

The data analysis technique in this study, researchers used two stages, namely descriptive statistical analysis and inferential statistical analysis with the partial least square approach (SMAR PLS).

\section{Hypothesis test}

This hypothesis testing was carried out by using the bottstrap resampling method developed by Geiser and Stone (Solimun, 2013). This hypothesis testing aims to answer whether the hypothesis is accepted or not. Testing is done with a critical point $(\mathrm{CR})$; P-value $<0.05(\mathrm{a}=0.05)$ means that the significance level of the parameter estimate in testing the hypothesis is $95 \%$ or $\mathrm{a}=0.05$.

\section{RESULTS AND DISCUSSION}

Validity and Reliability Test

Table 5.2 Final Results Recapitulation of the Validity and Reliability Test of Research Instruments

\begin{tabular}{|c|c|c|c|c|c|}
\hline \multirow[t]{2}{*}{ Variable } & \multirow[t]{2}{*}{ Indicator } & \multicolumn{2}{|l|}{ validity test } & \multicolumn{2}{|l|}{ Reliability test } \\
\hline & & Product Moment & information & Cronbach Alpha & information \\
\hline Innovation & $\mathrm{X} 1.1$ & 0,887 & Valid & & \\
\hline Product & $\mathrm{X} 1.2$ & 0,895 & Valid & 0,870 & Reliable \\
\hline (X1) & $\mathrm{X} 1.3$ & 0,898 & Valid & & \\
\hline \multirow{5}{*}{$\begin{array}{l}\text { Service Quality } \\
(\mathrm{X} 2)\end{array}$} & $\mathrm{X} 2.1$ & 0,655 & Valid & & \\
\hline & $\mathrm{X} 2.2$ & 0,827 & Valid & & \\
\hline & $\mathrm{X} 2.3$ & 0,831 & Valid & 0,837 & Reliable \\
\hline & $\mathrm{X} 2.4$ & 0,814 & Valid & & \\
\hline & $\mathrm{X} 2.5$ & 0,758 & Valid & & \\
\hline \multirow{4}{*}{$\begin{array}{l}\text { Customer } \\
\text { Satisfaction } \\
\text { (Y1) }\end{array}$} & Y1.1 & 0,915 & Valid & & \\
\hline & Y1.2 & 0,871 & Valid & & \\
\hline & Y1.3 & 0,853 & Valid & 0,910 & Reliable \\
\hline & Y1.4 & 0,909 & Valid & & \\
\hline \multirow{4}{*}{$\begin{array}{l}\text { Customer } \\
\text { Loyalty (Y2) }\end{array}$} & $\mathrm{Y} 2.1$ & 0,847 & Valid & & \\
\hline & Y 2.2 & 0,873 & Valid & & \\
\hline & Y2.3 & 0,867 & Valid & 0,897 & Reliable \\
\hline & Y 2.4 & 0,911 & Valid & & \\
\hline
\end{tabular}

Source: data processed, 2019 (Attachment: 8-10)

Based on the results of table 5.2 above, all statement items are said to be valid and reliable as a means of collecting data.

\section{Descriptive Statistical Analysis}




\section{Product Innovation}

The value of respondents' perceptions on each of the indicators of the product innovation variable, there are 3 indicators of new product development, indicators of design change and indicators of technical innovation. Of the three indicators above, it has an average value of 3.41-4.20, the mean value shows 3.56. In the good category value.

\section{Service quality}

The 5 indicators of service quality variables are tangibles indicators, reliability indicators, responsiveness indicators, assurance indicators, empathy indicators. The five indicators have an average value of 3.41-4.20 with a mean value of 3.72. In the good category value.

\section{Customer Satisfaction}

Respondents' perceptions of the 4 indicators on the satisfaction variable, namely service indicators, price indicators. Complete indicators and indicators as expected are considered good. The four indicators have an average value of 3.40-4.23, a mean value of 3.56. In the good category value.

\section{Customer Loyalty}

Of the 4 indicators in the customer loyalty variable, namely the brand indicator, the Repeat Purchase indicator, the Referalls indicator, the Retention indicator. The four indicators have an average value of $3.43-4.23$ with a mean value of 3.68 . Rated good category.

\section{Result of Inferential Analysis}

\section{Evaluation of Measurement Model (Outer Model)}

Convergent validity; as a construct measurement, it can be seen in outer loading (SmartPLS output). The indicator is considered valid if it has an outer loading value above 0.5 and or a TStatistics value above 1.96.

The results of the outer model examination are presented in Table 5.7, that the three indicators measuring the product innovation variable $(\mathrm{X} 1)$ are valid, the new product development indicator is the strongest measure of the product innovation variable (X1), because it has the largest outer loading value (0.907). .compared to the other two indicators.

Examining the service quality variable (X2), responsiveness is the strongest indicator in the service quality variable with an outer loading value of 0.832 .

Examining the customer satisfaction variable (Y1), the service indicator is the strongest indicator in the customer satisfaction variable with an outer loading value of 0.917. 
The evaluation results of the customer loyalty variable (Y2), the referrals indicator is the strongest indicator in forming loyalty with an outer loading value of 0.917.

The results of discriminant validity examination in this study in Table 5.7 show that the four variables have an AVE value above 0.5 and the root value of AVE ( $\mathrm{AVE}$ ) for each variable is greater with several correlation coefficients between variables. The results obtained indicate that the model has good discriminant validity.

Table 5.8. Evaluation Discriminant Validity

\begin{tabular}{|c|c|c|c|c|c|c|}
\hline \multirow{2}{*}{ Variable } & \multirow{2}{*}{ AVE } & \multirow{2}{*}{$\begin{array}{l}\sqrt{ } \\
\mathbf{A V E}\end{array}$} & \multicolumn{4}{|c|}{ Correlation } \\
\hline & & & X1 & $\mathrm{X} 2$ & $\mathbf{Y}_{1}$ & $\mathbf{Y}_{2}$ \\
\hline Innovation product (X1) & $\begin{array}{l}0,60 \\
8\end{array}$ & 0,779 & 1.000 & & & \\
\hline Quality service (X2) & $\begin{array}{l}0,79 \\
9\end{array}$ & 0,894 & 0.751 & 1.000 & & \\
\hline Customer satisfaction $\left(\mathrm{Y}_{1}\right)$ & $\begin{array}{l}0,78 \\
8\end{array}$ & 0,888 & 0.804 & 0.867 & 1.000 & \\
\hline Loyalty customer $\left(\mathrm{Y}_{2}\right)$ & $\begin{array}{l}0,76 \\
5\end{array}$ & 0,875 & 0.829 & 0.844 & 0.864 & 1.000 \\
\hline
\end{tabular}

Source: Primary data processed, 2019 (Attachment: 19)

Composite Reliability; aims to evaluate the reliability value between the indicator blocks of the constructs that form it. The composite reliability value is said to be good if it is above 0.70 .

Table 5.9. Value Composite Reliability

\begin{tabular}{|l|c|}
\hline Variable & Composite Reliability \\
\hline Innovation product (X1) & 0,922 \\
\hline Quality Service (X2) & 0,885 \\
\hline Satisfaction Customer ( $\left.\mathrm{Y}_{1}\right)$ & 0,937 \\
\hline Loyalty Customer $\left(\mathrm{Y}_{2}\right)$ & 0,929 \\
\hline
\end{tabular}

Source: Primary data processed, 2019 (Attachment: 18) 
The results of the composite reliability evaluation are presented in Table 5.9 above. Information can be obtained that the four latent variables used in this study are above 0.70 , so it can be stated that the indicator block is reliable or reliable in measuring the research variables.

\section{Evaluation of the Structural Model (Inner Model)}

The results of the structural model evaluation prove that the value of Q2 (0.965) is close to number 1. Thus, the results of this evaluation provide evidence that the structural model has a good goodness of fit model. These results can be interpreted that the information contained in the data, 96.5 percent can be explained by the model, while the remaining 3.5 percent is explained by errors and other variables not included in the model.

Table 5.11. Direct Effect Testing Results

\begin{tabular}{|c|c|c|c|c|}
\hline No & $\begin{array}{l}\text { Relationship } \\
\text { variables }\end{array}$ & $\begin{array}{l}\text { Path Coefficient } \\
\text { (Bootstrapping) }\end{array}$ & T-Statistic & Information \\
\hline 1 & $\begin{array}{l}\text { Innovation } \\
\text { Product }(\mathrm{X} 1) \rightarrow \text { Customer } \\
\text { Satisfaction }\left(\mathrm{Y}_{1}\right)\end{array}$ & 0,601 & 7,482 & Signifikan \\
\hline 2 & $\begin{array}{l}\text { Service Quality }(\mathrm{X} 2) \rightarrow \\
\text { Customer Satisfaction }\left(\mathrm{Y}_{1}\right)\end{array}$ & 0,358 & 4,286 & Signifikan \\
\hline 3 & $\begin{array}{l}\text { Innovation Product }(\mathrm{X} 1) \\
\rightarrow \text { Customer Loyalty }\left(\mathrm{Y}_{2}\right)\end{array}$ & 0,311 & 3,288 & Signifikan \\
\hline 4 & $\begin{array}{l}\text { Service } \\
\text { Quality }(\mathrm{X} 2) \rightarrow \text { Customer } \\
\text { Loyalty }\left(\mathrm{Y}_{2}\right)\end{array}$ & 0,338 & 3,323 & Signifikan \\
\hline 5 & $\begin{array}{l}\text { Customer Satisfaction }\left(\mathrm{Y}_{1}\right) \\
\rightarrow \text { Customer Loyalty }\left(\mathrm{Y}_{2}\right)\end{array}$ & 0,321 & 2,293 & Signifikan \\
\hline
\end{tabular}

Source: Primary data processed, 2019 (Attachment: 17)

(Figure 5.1) which describes the relationship between the variables in this study. 


\section{Figure 5.2. Hypothesis Test Result Path Diagram}

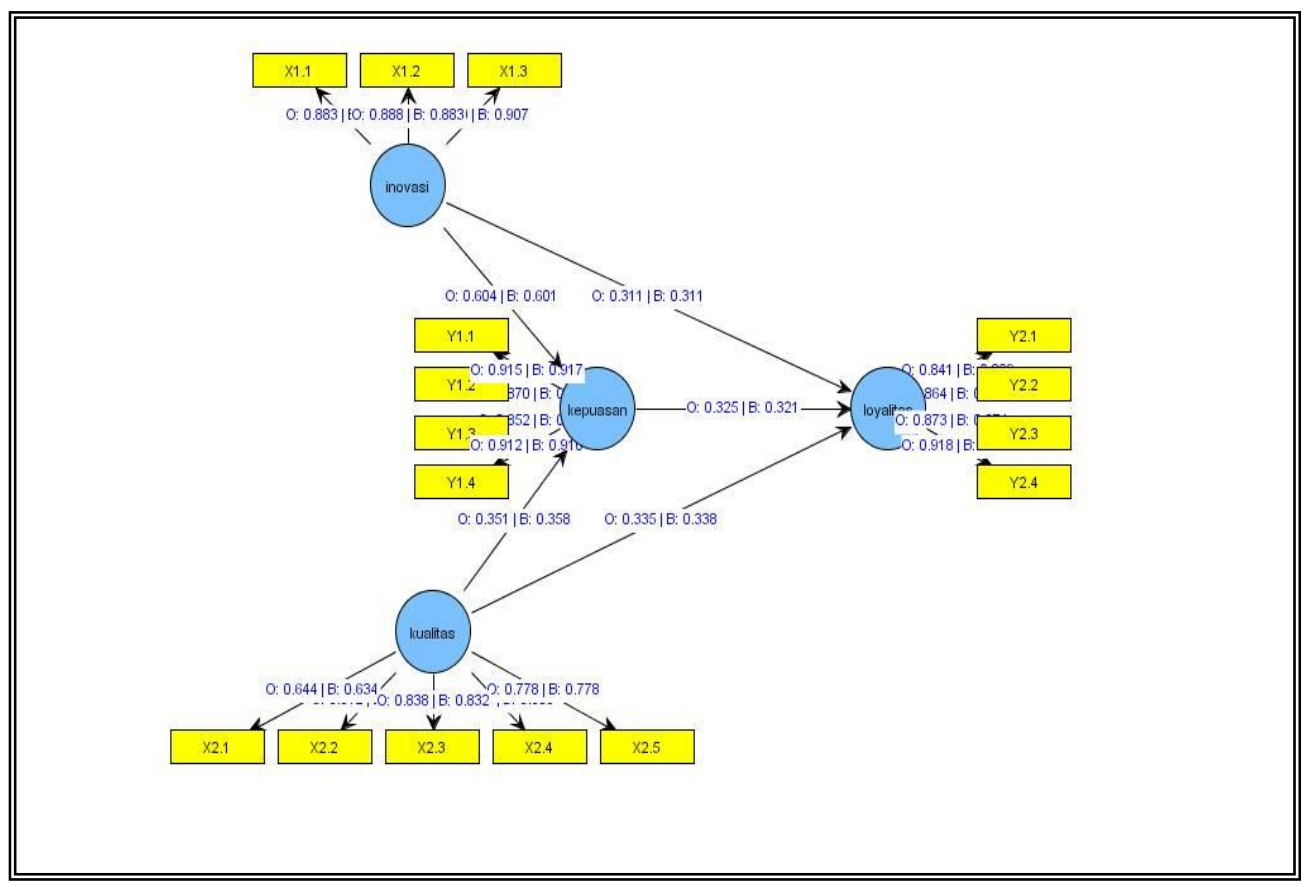

Source: Primary data processed, 2019 (Attachment: 19)

\section{Research Discussion}

\section{The Influence of Product Innovation on Customer Satisfaction}

The results showed that product innovation has a positive and significant effect on customer satisfaction, it can be accepted with a positive path coefficient value of 0.601 which indicates a positive relationship between product innovation and customer satisfaction with $\mathrm{T}$ statistic $=7.482$ (T-statistic $>1.96)$. Shows that product innovation has a significant effect on customer satisfaction. These results mean that product innovation has a positive and significant effect on customer satisfaction at the BNCTL Dili bank, the better the bank will make product innovation by making the process easier for customers to use bank products / services, innovating according to customer desires and serving customers professionally, so customers feel satisfaction with the services (various products) offered by the bank.

\section{The Effect of Service Quality on Customer Satisfaction}

The results of the research data analysis show that service quality has a positive and significant effect on customer satisfaction, it can be accepted with a positive path coefficient value of 0.358 indicating a positive relationship between service quality and customer satisfaction, and a T-statistic of 4.286 (T-statistic> 1.96) . Shows that service quality has a significant effect on 
customer satisfaction. This result means that service quality has a positive and significant effect on customer satisfaction at the BNCTL Dili bank. This explains that the better the service quality that BNCTL Dili bank has, by giving the impression of responsiveness, tangibles, reliability, assurance and empathy well, the customers are satisfied with the services provided by the BNCTL Dili bank.

\section{Effect of Product Innovation on Customer Loyalty}

The results showed that product innovation has a positive and significant effect on customer loyalty, it can be accepted with a positive path coefficient value of 0.601 which indicates a positive relationship between product innovation and customer loyalty with T-statistic $=7.482$ (T-statistic> 1.96). Shows that product innovation has a significant effect on customer loyalty. These results indicate that product innovation has a positive and significant effect on customer loyalty at the BNCTL Dili bank.

This means that product innovation carried out by BNCTL banks continuously, through design changes, technical innovation, new product development according to customer needs and desires, can increase customer loyalty.

\section{The Effect of Service Quality on Customer Loyalty}

The results of the research data analysis show that service quality has a positive and significant effect on customer loyalty, it can be accepted with a positive path coefficient value of 0.358 indicating a positive relationship between service quality and customer loyalty, while $\mathrm{T}$ statistic $=4.286$ (T-statistic $>1.96)$. Shows that service quality has a significant effect on customer loyalty. These results indicate that service quality has a positive and significant effect on customer loyalty at BNCTL Dili.

This explains that the better the quality of service provided by BNCTL banks to customers by increasing evidence (tangibles), reliability, responsiveness, assurance and empathy, this can create and increase customer loyalty.

\section{The Effect of Customer Satisfaction on Customer Loyalty}

The results of the research data analysis show that customer satisfaction has a positive and significant effect on customer loyalty, it can be accepted with a positive path coefficient value of 0.321 indicating a positive relationship between customer satisfaction and loyalty, while the value of T-statistic $=2.293$ (T-statistic $>1.96)$. Shows that satisfaction has a significant effect on 
customer loyalty. These results indicate that customer satisfaction has a positive and significant effect on customer loyalty at BNCTL Dili.

\section{CONCLUSIONS}

Based on the research findings and discussion results, it can be concluded:

1) Product innovation has a positive and significant effect on customer satisfaction. the better the BNCTL Dili bank is to innovate products by always creating new products according to customer desires, serving professionally and always making the process easier for customers to use bank products / services will be able to increase customer satisfaction.

2) Service Quality has a positive and significant effect on customer satisfaction. The better the BNCTL Dili bank employees have good appearance, bank employees always provide correct information, the ability of bank employees to serve quickly, bank employees have a polite attitude towards customers, and pay sincere attention to customers when serving. Will be able to increase customer satisfaction.

3) Product innovation has a positive and significant effect on customer loyalty. The better the BNCTL Dili bank is to innovate products by always creating new products according to customer desires, serving professionally and always making the process easier for customers to use bank products / services. Will increase customer loyalty.

4) Service Quality has a positive and significant effect on customer loyalty. the bank provides fast service, with good appearance, always provides correct information, by being polite and giving sincere attention to customers serving customers will be able to create customer loyalty

5) Customer Satisfaction has a positive and significant effect on customer loyalty. The bank offers a variety of products and services, the services provided are of high quality, the price of the products and services offered is in accordance with the quality and product innovation that is carried out in accordance with the wishes of the customer, is able to increase customer loyalty.

\section{Suggestion}

For the BNCTL Bank Dili. The influence of product innovation variables and service quality and customer satisfaction and loyalty has a positive and significant value. Therefore, it is hoped that the bank will serve more professionally. Bank employees look better and pay sincere attention in order to increase customer satisfaction and customer loyalty. The effect of customer satisfaction and loyalty has a positive and significant value. Therefore, it is hoped that the BNCTL Dili bank will offer more varied products that will be able to create and increase customer loyalty. 
For Further Researchers. The next researcher to research all BNCTL banks in Timor Leste. Because BNCTL bank is the only national bank owned by the State of Timor-Leste.

Further researchers with the existing phenomena and gaps can continue this research by adding variables of customer relationship marketing / CRM and Corporate Image which are variables not examined in this study.

\section{REFERENCES}

Arief, 2007. Pemasaran Jasa \& kualitas Pelayanan, Bayumedia Publishing, Malang.

Akbar, M.M. \& Prevez, M. 2009 Impact of Service Quality, Trust and Customer Satisfaction on Customer Loyalty.

Agbor, E. 2008. Creativity and inovation: the leadership dynamics strategic Leadership, Vol.1 Iss, 1, 2008,pp.39-45.

Assauri, S. 2013. Manajemen Pemasaran. Jakarta: Rajawali Pers.

Assauri, S. 2012. Trategic Marketing. Cetakan satu. Raja Grafindo Persada.Depok.http://repository.uin-suska.ac.id/15446/7/7.\%20BAB\%20II_2018975

Antanegoro, Y, RM,D, S., dan Fauzi S. 2017.“ Anlisis pengaruh inovasi produk, Inovasi layanan, kualitas pelayanan terhadap kepusan dan loyalitas” Jurnal Riset Bisnis dan management Tirtayasa.

Abdullah, M., Putit, L., \& Teo, C. 2014. Impact of Relationship Marketing tactics (RMT's) \& Relantionship quality on Customer Loyalty: A Study Within the Malaysian Mobile Telecommunication Industry. Procedia-Sosial and behavioral Sciences, 130, 371-378.

Arikunto S. 2002. Metodologi Suatu Pendekatan Propposal. Jakarta: PT. Rineka Cipta.

Buchari, A. 2007 Manjemen Pemasarandan dan Pemasaran Jasa. Edisi Revisi, Bandung CV. Alfabeta.

Cheng, C., Cheng, J.S and Tsou, H,T. 2012. Market Creating Service Innovation: Verification, and Its Association with new Service Development Customer Involvement.Journal of service Marketing, 26 (6): pp. 444-457.

Cheng, Yen-Chung, Yun-cheng Shen, Crystal Tzu-Yin Lee dan Fu-Kai Yu. 2017. Measuring Quality Variations in E-service. Journal off Service Theory and Practice, Vol. 27, Iss, 2,Pp. 427-452. 
Cooper, Robert G. 2000. Product Innovation and Technology and Strategic. Journal Research Technology Management. Pp 38-41

Crawford, C. Merle, and C, Antony di Benedetto.2000, New Product management. McGrawHill.USA

Drucker, P.F 1986. Inovation and Entrepreneurship practice and Principles. London: Heinemann

Elinawati, S. M \& Bode Lumanauw dan Ferdy Roring. 2017. Pengaruh Inovasi Produk, Harga, Citra Merek dan Kuliatas Pelayanan terhadap Loyalitas Pelanggan Mobil suzuki Ertiga”. Jurnal EMBA Vol.5 no.2 Juni 2017, hal 2230-2239, ISSN: 2303-1174.

Gatignon, H. \& Xuereb J.M. dalam Candra 2017. "Strategic Orientation of the fierm and product perfomance". Journal marketing Research.

Ghozali Imam. 2008. Struktur Equation Modeling, edisi II, universitas Diponegoro, Semarang.

Ghozali, Imam.2013. Aplikasi Analisis Multivariat dengan Program IBM SPSS.Edisi 7. Semarang: Penerbit Universitas Diponegoro. https://elib.unikom.ac.id/files/disk1/659/jbptunikompp-gdl-izmavitasa-32945-7unikom_i-i.pdf

Gumusluoglu, L., and Ilsev, A. 2009” Transfomational Leadership and Organizational Innovation: The Roles of Internal and External Suport for Innovation", Journal of Product innovation mangement, 26(3):pp 264-277.

Hair Josep.F.Jr. et al 2010. Multivariate Data Analysis Edition Person education limited. Harlow. England.

Hubeis, Musa. 2012. Manajemen Kreatifitas dan inovasi dalam bisnis. Penebit PT. Hecca. Mitra Utama. Jakarta.

Hurriyati, R., 2005. Bauran Pemasaran dan loyalitas Konsumen. Bandung: CV Alfabeta.

Jhone, A. 1999. Succesful Market Innovation. European Journal of Innovation Management. 2 (1):pp.6-11.

Kasmir, 2012. Dasar-dasar perbankan. PT. Raja Grafindo persada: Jakarta

Kolter, and Kevin Keller . 2013. Manjemen Pemasaran Jilid 2. Jakarta: Erlangga.

Kolter, P., dan Keller, K.L. 2013. Management Pemasaran. Jilis 2. Jakarta : Penertbit Erlangga.

Kolter, P., 2005, Manajemen Pemasaran, PT. Prenhallindo, jakarta.

Kolter, P., dan Keller, K.L. 2012. Marketing Mangement. 14th. Edition. United States of America: Pearson. http://repository.uin-suska.ac.id/15446/7/7.\%20BAB\%20II_2018975 
Kolter, P., dan Amstrong, G. 2012. Principles of Marketing Mangement. New Jersey: Prentice Hall. http://repository.uin-suska.ac.id/15446/7/7.\%20BAB\%20II_2018975

Khilmi, M., 2013” Pengaruh kualitas pelayanan, inovasi produk dan citra Perusahaan terhadap perusahaan dan loyalitas pelanggan Lion Air Surabaya Di Surabaya”. Sumber htt://eprint. Perbanas.ac.id.

Laemonta, J,. H., \& Metta, P., 2016. “ pengaruh inovasi dan kualitas layanan terhadap loyalitas pelanggan Terang Bulan-Martabak 93”. Jurnal Enterpreneur dan enterperneushipn volume 5, nomor 2, September 2016.

Lovelock, C., dan Wirtz, J. 2011. Service Marketing. New Jersey, USA: Pearson. Jurnal. Taufan Yunanda, ( 2013) Pengaruh diferensiasi produk dan Inovasi Produk Terhadap Loyalitas Konsumen. CV. Labonita Makmur.

Lupioyadi, R. 2001. Manajemen Pemasaran Jasa: Teori dan Praktek. Jakarta: Salemba Empat. Lupioyadi, R. 2008. Manajemen Pemasaran Jasa. Jakarta: Salemba Empat.

Meeus. M., \& Edquist, C. 2006. Introduction to part I: product and process Innovation in J.H.M. Eds. (Ed). Innovation Science, and Institutional Change: Oxford: Oxford University Press, 23 (2):23-37.

Mowen, John, C dan Michael, M. 2002. Perilaku Konsumen. Dialihbahasakan oleh Dwi Kartini Yahya. Jilid 2. Jakarta Erlangga.

Mowen, J. C., \& Minor, M. 2005 Consumer Bihaviour. Boston :Irwin

Puspitasari, A. N. And Ferdinand, A.T., 2011. Analisis Pengaruh Kualitas Produk dan Kualitas Pelayanan terhadap kepuasan pelanggan. Untuk mendorong Minat Belu Ulang (Studi pada Pengguna Nokia Di Semarang) (Doctoral Dissertation Universitas Diponegoro).

Putri, R, W., Suharyono., Fanami, D., 2015. "Pengaruh Kualitas Pelayanan terhadap Kepuasan dan Loyalitas pelangga” Jurnal Administrasi Bisnis (JAB)| Vol. 1 No. 1, Januari 2015. administrasibisnis.studentjournal.ub.ac.id.

Putri, Y, L., Utomo H. 2017.” Pengaruh kualitas pelayanan terhadap loyalitas pelanggan dengan kepuasan sebagai intervening (studi persepsi pada pelanggan dian comp ambarawa). Jurnal Among Makarti Vol.10 No.19, Juli 2017.

Riduwan, R, A, E. (201. Cara Mudah Belajar SPSS Dan Aplikasi Statistik Penelitian. Bandung. Penerbit. Alfabeta. 
Saidana, B., \& S., A., 2012, Pengaruh Kualitas Produk, Kualitas Layanan terhadap kepuasan konsumen dan Minat Beli pada Ranch Market, Jurnal Riset Manjemen Sains Indonesia JRMSI / Vol.3, No. 1, 2012.

Sinurat E., S., M.,; Bode L., dan F., R., 2017. Pengaruh inovasi produk, Harga, Citra Merek dak kualitas pelayanan terhadap Loyalitas pelanggan, Mobil Suzuki Ertiga “ Jurnal EMBA cvol, 5 no. 2 Juni 2017,Hal 2230-2239,ISSN: 2303-1174

Solimun. (2002). Multivariate Analysis Structural Equation Modelling (SEM) Lisrel dan Amos. Fakultas MIPA. http://repository.unair.ac.id/30611/5/Arya\%20Bayu_Bab4.pdf

Sukarmen, P., A., S., dan Wulandari. D., 2013 Analisis pengaruh Inovasi Produk terhadap kepuasan konsumen dengan keunggulan bersaing sebagai variabel intervening pada produk Gula Pasir sebelas (GUPALAS) Pabrik Gula Semboro PTP Nusantara XI (Persero). JEAM, Vol. XII No.!. Hal. 64-78. ISSN: 1412-5366.

Sugiyono. 2011. Metode Research and Development. Bandung: Alfabeta

Sugiyono. 2010. Metode penelitian Pendidikan Pendekatan kuantitatif, Kualitatif dan R\&D. Bandung. Alfabeta.

Supramono dan Oktavian.J. 2005. Desain proposal Penelitian Studi pemasaran. Yokyakarta: penerbit Andi

Starini, H. 2013. Pengaruh Kualitas pelayanan terhadap Loyalitas konsumen dengan kepuasan sebagai Variabel mediasi (pada Studi Toko Basuki Jaya Yokyakarta). Skripsi Tidak diterbitkan. Universitas Negeri Yokyakarta.

Tidd,J., Bessant, J., and Pavid, K. 2005. Manging Innovation : Integrating Technology, Market and Organizational Change, Third edition, Wiley. Managing innovation for global competitiveness.project symposium. Tokyo, 16 March 2009 pp 09.

Tjiptono, F., 2007. Service, Quality and Satisfatiob. Edisi Pertama, Yogyakarta: Andi Ofset

Tjiptono, F., 2011. seri 01-manajemen dan Strategi Merek. Penerbit Andi, Yogyakarta. https://media.neliti.com/media/publications/85491-ID-pengaruh-marketing-mix-7pterhadap-keput.

Tjiptono, F., 2000, manjemen jasa, Yokyakarta: Andi Offset

Tjiptono, F., 2005. Prinsip-prinsip Total quality service. Yokyakarta: Andi.

Tjiptono, F., dan Chandra, G. 2011. Service, Quality and Satisfaction. Yogyakarta: CV Andi offset. 
Tjiptono Fandy, 2008. Strategi manajemen pemasaran, Edisi Kedua, penerbit Andi Offset.

Tjiptono Fandy, 2008. Service manajemen mewujudkan Layanan Prima. Yokyakarta< Penerbit: Andi.

Uce, Indahyanti. 2013. Penulisan karya ilmiah, panduan awal menyusun skripsi dan tugas akhir. Jakarta: Salemba Empat. https://elib.unikom.ac.id/files/disk1/659/jbptunikompp-gdlizmavitasa-32945-7-unikom_i-i.pdf

Yap, B. W., Ramayah, T., \& Shahidan, W. N. W. 2012 Satisfaction and strust on Customer Loyalty: a PLS Aproach. Jurnal Business Strategy Series, 154-167.

Yulimindra, I., Samir., Wijayanto, G, 2015." Pengaruh kualitas layanan dan inovasi terhadap citra perusahaan dan loyalitas nasabah pada pt. bank riau kepri 468 Vol. VII No. 3 September 2015 jurnal tepak manajemen bisnis.

Yordyanto Hermanus Laemonta dan Metta Padmali 2016, Jurnal Entrepreneur dan Entrepreneurship Volume 5, Nomor 2, September 2016

Zakaria B. Rahman, K. Othman, N. Yunus, M. Dzulkipl, M. Osman, 2004. Customer Satisfaction and loyalty in Retail Industry. Jurnal BehavioralSciences.Vol.129.Pp.23-30.

Sumber Web

https://www.bnctl.tl

https://mandaridili.tl 